\title{
В.В.Кабин ${ }^{1}$, Б.Л.Агапов ${ }^{1}$, А.А.Кузнецов ${ }^{2}$, А.Н.Матросов ${ }^{2}$ \\ К 110-ЛЕТИЮ ФЕДЕРАЛЬНОГО КАЗЕННОГО УЧРЕЖДЕНИЯ ЗДРАВООХРАНЕНИЯ «АСТРАХАНСКАЯ ПРОТИВОЧУМНАЯ СТАНЦИЯ»
}

\author{
${ }^{\prime}$ ФКУЗ «Астраханская противочумная станция», Астрахань; \\ ${ }^{2}$ ФКУЗ «Российский научно-исследовательский противочумный институт «Микроб», Саратов
}

Приводится исторический очерк деятельности одного из старейших противочумных учреждений России Астраханской противочумной станции. Специалисты станции внесли большой вклад в развитие учения о природной очаговости чумы и других опасных инфекций, обеспечение и проведение мероприятий по эпидемиологическому надзору и профилактике чумы и других особо опасных инфекционных болезней на территории Северо-Западного Прикаспия.

Ключевые слова: Астраханская противочумная станция, эпидемиологический надзор, чума, холера, туляремия, вирусные инфекции.

\section{V.V.Kabin, B.L.Agapov, A.A.Kuznetsov, A.N.Matrosov}

\section{To $110^{\text {th }}$ Anniversary of the Federal Public Health Institution "Astrakhan Plague Control Station"}

\author{
Astrakhan Plague Control Station, Astrakhan; Russian Research Anti-Plague Institute “Microbe”, Saratov
}

Presented is a historical essay on the work of one of the oldest Russian anti-plague institutions - "Astrakhan Plague Control Station". Noted is the fact that specialists of this institution made a substantial contribution to the development of the theory of plague natural focality and other contagious infections, as well as to the provision for and implementation of measures for epidemiological surveillance and prophylaxis of plague and other particularly dangerous infectious diseases in the territory of the North-West Caspian sea region.

Key words: Astrakhan plague control station, epidemiological surveillance, plague, cholera, tularemia, viral infections.

В 2011 г. исполнилось 110 лет старейшему учреждению противочумной службы России Астраханской противочумной станции. В июле 1901 г. в связи с эпидемическими вспышками чумы в Астраханском крае по решению правительства была учреждена первая в стране противочумная лаборатория в Астрахани. До 1914 г. лаборатория находилась в ведении управления Главного врачебного инспектора МВД, в 1914-1917 гг. - института экспериментальной медицины Санкт-Петербурга. Уже в дореволюционный период она из провинциальной бактериологической лаборатории выросла в научный центр по борьбе с чумой на юго-востоке России. Штат ее постепенно увеличивался. В это время на базе Астраханской лаборатории проводили свои исследования выдающиеся ученые - доктор медицинских наук, профессор, впоследствии академик Д.К.Заболотный (1911 г.), доктор медицинских наук В.И.Исаев (1901, 1905 гг.), а также профессор, видный отечественный биолог, иммунолог и бактериолог, почетный член Петербургской АН и многих иностранных академий, лауреат Нобелевской премии, доктор медицинских наук И.И.Мечников (1911 г.). С 1901 по 1922 год в Астраханской лаборатории работали известные исследователи - врачи И.А.Деминский, Е.И.Нагулевич, И.В.Страхович, С.В.Суворов, В.И.Иорданский, принимавшие непосредственное участие в локализации и ликвидации вспышек чумы $[23,24]$. В этот период в отечественной и зарубежной литературе специалистами лаборатории были опубликованы научные работы, ряд которых имеет мировое значение. К ним можно отнести работы И.А.Деминского и Н.Н.Клодницкого, в которых обосновывалась эндемичность природных очагов чумы и была показана роль верблюдов в распространении инфекции [3, 8]. В 1912 г. И.А.Деминский, заразившись чумой при лабораторном вскрытии малых сусликов, ценой своей жизни доказывает, что источником чумы в Астраханских степях являются эти грызуны.

С 1917 по 1922 год лаборатория подчинялась Губернскому отделу здравоохранения. В эти годы она переживала тяжелые времена: материальных средств на оснащение и содержание лабораторной базы не хватало, штат сокращался, методы диагностики, лечения и профилактики чумы отсутствовали или оказывались неэффективными.

В 1922 г. Астраханская бактериологическая лаборатория в числе других, расположенных на юге России, перешла в непосредственное подчинение Саратовского государственного краевого института микробиологии юго-востока РСФСР «Микроб», в штате которого находилась до 1935 г. В этот период укрепляется лабораторная база учреждения, увеличивается число квалифицированных кадров. Специалисты лаборатории участвуют в ликвидации 
эпидемических вспышек чумы в Нижнем Поволжье, совместно с сотрудниками института ведут научные исследования по эпидемиологии, эпизоотологии и лечению чумы и других опасных инфекций в регионе. С.В.Суворов, А.А.Вольферц и М.М.Воронкова впервые в стране дифференцировали туляремию как нозологическую единицу, доказали эпидемичность Нижнего Поволжья по этой инфекции, описали клинику и лабораторную диагностику заболевания [26]. В 1926 г. в с. Яндыки было открыто противочумное отделение Астраханской лаборатории.

В 1930-1950 гг. сформировались организационные основы эпидемиологического надзора за чумой: в структуре противочумных подразделений появились станции, отделения и сезонные противоэпидемические отряды. В 1935 г. Астраханская лаборатория была реорганизована в противочумную станцию и перешла в ведение Народного комиссариата здравоохранения СССР. В этом же году открывается противочумное отделение в с. Енотаевка, в 1938 г. на станции Досанг, а в 1950 г. - в г. Харабали. В 1930-1950 гг. станция значительно укрепляется кадрами врачей и зоологов. Развивается материальнотехническая база учреждения: строятся здания, расширяется гужевой, появляется автомобильный и речной транспорт. В противочумной практике начинает использоваться малая авиация. В этот период противочумная станция разрабатывает и проводит профилактические мероприятия по чуме, холере и другим особо опасным инфекциям на территории Астраханской, Ростовской, Калмыцкой и ЗападноКазахстанской областей.

Под руководством института «Микроб», совместно со специалистами Астраханской, Гурьевской и Уральской противочумных станций в 50-е годы был разработан приманочный метод борьбы с песчанками, в том числе с использованием авиации $[1,17,20]$. Позитивный опыт борьбы с малыми сусликами и мелкими песчанками позволил резко снизить эпизоотическую активность закрепленной территории очагов и соответственно эпидемический потенциал. За разработку и внедрение эффективных методов борьбы с песчанками сотрудники станции О.И.Вугмейстер, Н.И.Калабухов и Н.Н.Тропин были удостоены звания лауреатов Государственной премии. В это же время начинают разрабатываться методы специфической профилактики чумы [14, 18]. В очагах чумы проводятся исследования по фауне грызунов и их эктопаразитов $[5,19]$. На фоне активизации эпизоотий чумы в 50-60-е годы под руководством М.И.Леви на станции впервые стали изучаться иммунологические методы диагностики чумы с последующим внедрением их в широкую практику эпизоотологического обследования природных очагов чумы. Уникальные эксперименты А.И.Штельмана, посвященные исследованиям популяций малых песчанок, позволили определить их значение в эпизоотологии чумы [28, 29].

В 1970-1975 гг. на фоне эпидемических вспы- шек холеры на юге европейской части страны Астраханская противочумная станция возглавила лабораторную службу по диагностике, лечению и профилактике холеры. Специалисты принимали непосредственное участие в ликвидации вспышек этого заболевания в регионе.

В 1970-1990 гг. специалисты станции принимали участие в разработке и внедрении в практику серологических методов исследования проб на чуму и холеру, что дало возможность повысить результативность проводимых диагностических исследований. В практике работы противоэпидемических отрядов для оперативной доставки лабораторного материала, грузов и людей на всей территории станции используются самолеты АН-2 и вертолеты К-26. Особого внимания в этот период заслуживают разработки новых методов учета грызунов, работы по картографированию поселений сусликов, малых песчанок, изучению пространственной структуры и ландшафтной приуроченности эпизоотий чумы. Исследования зоологов Г.Б.Постникова, Б.С.Варшавского, О.К.Дробинского, А.И.Дмитриева, В.Л.Скиртачева, А.А.Кузнецова, А.Н.Матросова, Э.Л.Тихомирова и др. позволили вести поиски эпизоотий чумы и наблюдение за популяциями носителей и переносчиков чумы более направленно $[2,4,6,12,15,16,21$, $22,25,27]$. Опытные научно-исследовательские изыскания по вопросам борьбы с грызунами позволили объективно оценить эффективность авиационноприманочного метода дератизации и отказаться от широкомасштабных обработок в природных очагах чумы $[11,13]$. Специалисты станции провели большую работу по изучению неорганизованного туризма, что было чрезвычайно важно для оценки риска заражения населения в природных очагах чумы и туляремии. Были начаты исследования природной очаговости вирусных инфекций. В частности, с участием специалистов станции была расшифрована этиология нового риккетсиоза, названного в дальнейшем Астраханской пятнистой лихорадкой [7].

В тяжелые 90-е годы станция сумела сохранить костяк опытных и квалифицированных специалистов, проводила все мероприятия по профилактике чумы и других опасных инфекций в зоне своей деятельности. Площади обследуемых на чуму природных очагов несколько сократились: восточные участки ВолгоУральского междуречья стали контролироваться противочумными учреждениями Казахстана. Несмотря на это на станции велись научно-исследовательские работы по изучению факторов очаговости чумы и других опасных инфекций [9].

В настоящее время Астраханская противочумная станция является одним из наиболее крупных противочумных учреждений России. Эпидемиологический надзор за чумой и другими опасными природноочаговыми инфекционными болезнями осуществляется на территории площадью 68700 кв. км. в административных границах Астраханской области, части Волгоградской области и Республики Калмыкия. 
Большой объем работы проводится станцией по оказанию консультативной, методической и практической помощи учреждениям Роспотребнадзора, органам управления здравоохранения субъектов Российской Федерации по вопросам санитарной охраны территории, организации и проведения профилактических и противоэпидемических мероприятий при возникновении чумы и других особо опасных инфекционных болезней, их лабораторной диагностики, соблюдения требований безопасности работ с микроорганизмами I-II групп патогенности.

Станция является региональным центром мониторинга за возбудителями инфекционных болезней I-II групп патогенности.

На станции функционирует отдел подготовки лаборантов, на базе которого проводятся курсы первичной специализации и усовершенствования лаборантов-бактериологов по особо опасным инфекциям.

В настоящее время штат Федерального казенного учреждения здравоохранения «Астраханская противочумная станция» Федеральной службы по надзору в сфере защиты прав потребителей и благополучия человека составляет 248 единиц, в том числе 54 специалиста с высшим образованием. Ученую степень кандидата наук имеют 5 сотрудников станции, 80 \% врачей, зоологов и лаборантов имеют высшую и первую квалификационную категорию.

Лаборатории и отделы станции и противочумных отделений укомплектованы современным оборудованием, позволяющим использовать как классические методы лабораторного анализа, так и передовые методы экспресс-диагностики (ПЦР в режиме реального времени, иммуноферментный анализ, люминесцентная микроскопия). Наличие современного навигационного и информационно-коммуникационного оборудования позволяет внедрять в практику эпидемиологического надзора ГИС-технологии.

Вся практическая и научная деятельность учреждения на протяжении многих лет неразрывно связана с Российским научно-исследовательским противочумным институтом «Микроб», который с момента своего основания оказывал и оказывает станции всестороннюю научно-методическую и практическую помощь. В разные годы большую консультативную помощь оказывали профессор, доктор биологических наук Ю.К.Эйгелис, кандидат медицинских наук А.И.Кологоров, доктор медицинских наук С.Н.Дальвадянц, доктор биологических наук А.А.Кузнецов.

За 110 лет существования Астраханской ПЧС сменилось несколько поколений специалистов и обслуживающего персонала [10]. В стенах учреждения сформировались и долгие годы трудились такие талантливые организаторы здравоохранения, как эпидемиологи С.В.Констансов, Н.Н.Клодницкий, Е.И.Нагулевич, Е.И.Новикова, Ф.В.Горбунов, П.М.Кучеров, А.Ф Оптякова, А.А.Рожков, И.Я.Журавлев, В.С.Буркин, А.А.Илюхин, А.К.Рогаткин,
В.А.Кабин, Б.Л.Агапов, В.А.Лещук. Большой вклад в оперативную работу станции в разные годы внесли зоологи - заведующие лабораториями П.И.Зинин, А.А.Рожков, С.С.Марышев, Б.С.Варшавский, Т.А.Козлова, В.П.Осипов, В.А.Бондарев. На Астраханской противочумной станция были воспитаны квалифицированные кадры ученых: доктора наук Н.И.Калабухов, В.С.Замараев, А.А.Кузнецов, А.И.Дмитриев, А.Н.Матросов, кандидаты наук С.В.Суворов, А.И.Штельман, В.С.Буркин, А.А.Илюхин, В.Г.Мацуга, А.В.Пилипенко, Е.И.Новикова, А.К.Рогаткин, Ю.А.Штельман, 3.С.Павленко, С.В.Андросова, В.И.Журавлев, К.И.Деревянченко, Н.Н.Тропин, Б.С.Варшавский, Э.А.Сувернева, В.Л.Скиртачев, Т.А.Козлова, Н.З.Настюков, Э.Л.Тихомиров, М.М.Шилов, В.И.Касаткин, Н.И.Морозкин, В.П.Булычев. Заслуживает глубокого уважения самоотверженный труд врачей и зоологов станции, долгие годы обеспечивающих здоровье населения в регионе: В.Т.Товстухи, А.В.Гненюка, П.М.Малькова, Н.М.Бондаренко, Ю.В.Бондаренко, В.Н.Нежневой, А.И.Яценко, Н.М.Яценко, В.Е.Муромцева, В.И.Мазурова, Т.В.Петрушиной, С.С.Соломатина, В.А.Чуринова, П.Ф.Трещилина, А.Г.Перервы, Б.М.Паршина, Т.П.Мацуги, Т.А.Богдановой, С.А.Богданова, Л.И.Товстуха, О.Л.Васильковой, Т.П.Давыдовой, Г.Г.Чивилевой, Н.Г.Путилиной, Г.И.Мальковой, Э.Б.Духовской, В.К.Синцова, С.М.Голосовского, В.С.Манжиевой, Т.С.Ким, Л.И.Голубевой, В.Л.Голубева,А.А.Глотова,И.А.Бахтигозина, В.К.Чехонина, Т.А.Бочарниковой, В.В.Дубровина, В.П.Буниной, П.С.Дубягина, А.А.Рожкова, Р.Н.Варшавской, В.В.Ларина, Л.И.Беляевой, Л.В.Мещеряковой, Н.И.Асанова и др.

Труд многих работников станции по борьбе и профилактике особо опасных инфекций отмечен правительственными наградами и почетными званиями. Нынешнее поколение чумологов состоит из высококвалифицированных ветеранов и молодых специалистов, принимающих эстафету своих опытных коллег [10].

В юбилейный год станция, как структурная единица Роспотребнадзора, бережно хранит и чтит традиции отечественной медицины и неуклонно развивает свой потенциал, внося вместе с другими учреждениями службы посильный вклад в обеспечение санитарно-эпидемиологического благополучия населения страны.

\section{СПИСОК ЛИТЕРАТУРЫ}

1. Бочарников О.Н., Карпузиди К.С., Климченко И.З., ТерВартанов В.Н., Тинкер И.С., Шишкин А.К., Ширяев Д.Т. Опыт работ по ликвидации энзоотии чумы в очаге Северо-Западного Прикаспия. В кн.: Природная очаговость и эпидемиология особо опасных инфекционных заболеваний. Саратов; 1959. С. 235-46.

2. Варшавский Б.С., Буркин В.С., Илюхин А.А., Оптякова А.Ф., Бондарев В.А., Зурилина Р.С., Матросов А.Н., Сувернева Э.А., Тропин Н.Н., Чикризов Ф.Д. Материалы по распространению и численности серой крысы в Астраханской области. В кн.: Экология и медицинское значение серой крысы (Rattus norvegicus Berk.). М.; 1983. С. 28-30.

3. Деминский И.А. Чума в Астраханской губернии за 10 лет 
(1899-1909 гг.). В кн.: Тр. съезда участн. противочумн. мероприятий в Астраханской губернии и Уральской области. Астрахань; 1910. C. 3-63.

4. Дмитриев А.И. Некоторые данные к палеогенезу природного очага чумы Северо-Западного Прикаспия. В кН.: Эпидемиология и эпизоотология чумы. Саратов; 1980. С. 23-8.

5. Дойников А.В., Деревянченко К.И., Казаниева Ю.М., Чернова Н.И. Блохи грызунов песчаной зоны левобережья Астраханской области. Сб. трудов Астраханской противочумн. станции. Астрахань; 1955. 1:302-55.

6. Дробинский О.К. Анализ текущего состояния популяций песчанок и блох в Волго-Уральских песках в связи с проблемой прогнозирования эпизоотий чумы. Пробл. особо опасных инф. 1972; 3:21-6.

7. Кабин В.В., Ветлугина К.Ф., Андросова С.В. и др. О новом заболевании риккетсиозной этиологии в Астраханской области. В кн.: Итоги и перспективы профилактики особо опасных инф. Астрахань; 1989. С. 56-7.

8. Клодниикий H.H. Чума верблюдов и значение ее в эпидемиологии Астраханской чумы. В кн.: Тр. съезда по борьбе с чумой и сусликами. Самара; 1914. С. 335-49.

9. Козлова Т.А., Попов Н.В, Кузнеиов А.А. Влияние гидрологических показателей на эпизоотическую активность Прикаспийского песчаного очага чумы. Деп. в ВИНИТИ, 25.02.94. № 467-В.94. Саратов, Астрахань; 1994.8 с.

10. Кологоров А.И., Кутырев В.В., Кабин В.В. Вклад специалистов Астраханской противочумной станции в теорию и практику борьбы с особо опасными инфекциями. В кн.: Природноочаговые особо опасные инфекции на юге России, их профилактика и лабораторная диагностика. Астрахань; 2001. С. 1-5.

11. Кузнечов А.А., Новохатка А.Д. Опыт количественной оценки противоэпизоотической эффективности борьбы с носителями чумы в Волго-Уральских песках. Деп. во ВНИИМИ МЗ СССР № 5394-82. Саратов; $1982.21 \mathrm{c}$.

12. Кузнеиов А.А., Эйгелис Ю.К., Варшавский Б.С., Дмитриев А.И., Дубровин В.В., Касаткин В.И., Матросов А.Н., Рожков А.А., Скиртачев В.Л. Определение численности мелких песчанок и эффективности борьбы с ними методом пунктов учета в Волго-Уральских песках. В кн.: Эпизоотология и профилактика природно-очаговых инфекций. Саратов; 1982. С. 59-64.

13. Кузнечов А.А. Матросов А.Н. Влияние истребительных мероприятий на размножение и смертность малых песчанок Волго-Уральских песков. В кн.: Вопросы природной очаговости и эпидемиологии особо опасных инфекций. Саратов; 1985 C. $62-7$.

14. Лалазаров Г.А. Экспериментальное изучение неотложной специфической профилактики первичной легочной чумы Тр. Астраханской противочумн. станции. 1958; 2:109-27.

15. Матросов А.Н., Эйгелис Ю.К., Кузнеиов А.А. Опыт использования аэрофотоматериалов для сопряженного зоологического и ландшафтного картографирования. Современные аспекты профилактики зоонозных инфекций. 1984; 1:39-41.

16. Матросов А.Н., Эйгелис Ю.К., Кузнеиов А.А., Ерофеев A.B., Чекашов B.H. Структура зонального ландшафта запада Волго-Уральского песчаного очага чумы. В кн.: Природная очаговость и профилактика зоонозов. Саратов; 1987. С. 3-10.

17. Миронов Н.П. О кратности обработок земель от сусликов с целью ликвидации чумного очага в Северо-Западном Прикаспии. Тр. Рост.-н/Д противочумн. ин-та. 1957; 13:17-50.

18. Новикова Е.И., Гурьева Е.П. Опыт прививки людей ассоциированной вакциной из живой противочумной EV и убитой тривакцины ТАВ. Тр. Астраханской противочумн. станции. $1958 ; 2: 144-54$.

19. Новикова Е.И., Тропин Н.Н., Деревянченко К.И.,
Рожков А.А., Штельиман А.И., Гусева Н.А., Павлова А.А. Эпизоотологический очерк Аксарайских песков в районе стыка Западно-Казахстанской, Гурьевской и Астраханской областей (по районированию 1952 г.). Тр. Астраханской противочумн. станции. 1958; 2:26-54.

20. Постников Г.Б., Копиев В.В., Дубягин П.С., Тарасов И.А., Тормасин E.C. Некоторые особенности авиационного способа борьбы с полуденными и гребенщиковыми песчанками. Тр. Астраханской противочумн. станции. 1958; 2:203-36.

21. Постников Г.Б., Ротшильд Е.В., Бунин В.А., Давыдов Е.Н., Иргискин С.И., Лушников В.И., Шукашева С.И., Пилипенко $A . B$. Пространственная структура эпизоотий чумы среди гребенщиковых и полуденных песчанок в песках Волго-Уральского междуречья. В кн.: Экология и медицинское значение песчанок фауны СССР. М.; 1977. С. 341-3.

22. Постников Г.Б., Солдаткин И.С., Ротиильд Е.В., Чикрозов Ф.Д. Численность песчанок и эпизоотии чумы среди них на небольшом участке Волго-Уральских песков. В кн.: Вопр. природ. очаговости и эпидемиол. особо опасных инф. Саратов; 1985. C. 42-9.

23. Рогаткин А.К. История создания и деятельности Астраханской противочумной станции. Астрахань; 1991. 20 с.

24. Рогаткин А.К., Букаева И.Н. Некоторые исторические вехи существования Астраханской противочумной станции в вековом пути противочумной службы. В кн.: Природно-очаговые особо опасные инфекции на юге России, их профилактика и лабораторная диагностика. Астрахань; 2001. С. 5-10.

25. Скиртачев В.Л., Беляева Л.И., Мешерякова Л.В. Размножение полуденных и гребенщиковых песчанок в естественных и искусственно разреженных популяциях. В кн.: Эпидемиология и профилактика природноочаговых инф. Саратов; 1981. С. 117-22.

26. Суворов С.В., Вольфери А.А., Воронкова М.М. Туляремиеподобные заболевания в пределах СССР. II. Чумоподобные лимфадениты в районе Астрахани. Вестн. микробиол., эпид. и паразитол. 1928. С. 293-9.

27. Тихомиров Э.Л. Некоторые особенности энзоотии чумы в Прикаспийском Северо-Западном (Прикаспийском песчаном) очаге чумы. В кн.: Природная очаговость, микробиол. и профил. зоонозов. Саратов; 1989. С. $16-22$.

28. Штельман А.И. Опыт проверки эффективности реакции нейтрализации антител при эпизоотологическом обследовании на чуму. В кн.: Матер. юбил. конф. Уральской противочумн. станции. Уральск; 1964. С. 356-8.

29. Штельман А.И., Рожков А.А. Некоторые вопросы экспериментальной чумы у полуденных и гребенщиковых песчанок. Сб. трудов Астраханской противочумн. станции. 1955; 1:5-25.

Authors:

Kabin V.V.,Agapov B.L. Astrakhan Plague Control Station. Kubanskaya St., Astrakhan, 414000, Russia. E-mail: antichum@astranet.ru

Kuznetsov A.A., Matrosov A.N. Russian Research Anti-Plague Institute "Microbe". Universitetskaya St., 46, Saratov, 410005, Russia. E-mail: rusrapi@microbe.ru

Об авторах:

Кабин В.В., Агапов Б.Л. Астраханская противочумная станция. 414000, г. Астрахань, ул. Кубанская, 3. E-mail: antichum@astranet.ru

Кузнецов А.А., Матросов А.Н. Российский научно-исследовательский противочумный институт «Микроб». 410005, Саратов, ул. Университетская, 46. E-mail: rusrapi@microbe.ru

\section{Редакиионный совет и редакиионная коллегия научно-практического журнала «Проблемы особо опасных инфекиий» поздравляют с юбилеем}

\section{Эльзу Афанасьевну Москвитину - доктора медицинских наук, заведующего отделом эпидемиологии Ростовского-наДону научно-исследовательского противочумного института,}

Владимира Ивановича Илюхина - профессора, доктора медицинских наук, заслуженного деятеля науки Российской Федерации, заведующего отделом сапа и мелиоидоза Волгоградского научно-исследовательского противочумного института

и желают им больших творческих успехов, здоровья и благополучия. 